\title{
Electrical/Electronic Property Problem
}

National Cancer Institute

\section{Source}

National Cancer Institute. Electrical/Electronic Property Problem. NCI Thesaurus. Code C63007.

Problem associated with a failure of the electrical circuitry of the device. 